\title{
ALIEN NEIGHBOURS: FOREIGNERS IN CONTEMPORARY SHANGHAI
}

\author{
Laura DE GIORGI \\ Department of Asian and North African Studies, Ca' Foscari University of Venice, \\ Address: Dorsoduro 3462, 30123 Venice, Italy \\ E-mail:degiorgi@unive.it
}

Received 07 October 2016; accepted 05 April 2017

\begin{abstract}
One distinctive facet of Shanghai's cosmopolitanism and openness to the outer world is the foreign presence in the city. Partially reviving the myth of the old pre-1949 Shanghai, in the last twenty years Shanghai has become again a pole of attraction for foreign migrants, and it actually hosts one of the most numerous community of residents of alien nationality in the People's Republic of China. Drawing from sociological and ethnological literature, from official reports and media coverage of the topic, this paper overviews the impact of foreign communities in Shanghai and investigates how Shanghai local migration policies and media discourse shape the meaning of this phenomenon with respect to the definition of Shanghai's identity as a globalizing and a Chinese metropolis as well.
\end{abstract}

Keywords: foreign communities, migration to China, cosmopolitanism, Chinese nationalism, Shanghai urban identity, Chinese internationalisation.

\section{Introduction}

The distinctive feature of Shanghai's brand as the most international metropolis of China is the foreign presence inscribed in its urban identity. The Western-style riverfront on the Huangpu, known as the Bund, and the buildings and avenues of the pre-1943 International and French Concessions, continuously remind residents and tourists of how deeply Shanghai's historical development has been tied to the presence of a lively foreign community. Before 1949, these areas made the city simultaneously a symbol of both China's colonial subjugation and China's modernity and cosmopolitanism. This international and Westernised identity was considered a stigma for almost forty years after the People's Republic of China was established in 1949. Shanghai's urban face became that of a large industrial Chinese city, with the historical significance of being the cradle of Chinese revolution against imperialism (Bérgère 2009; Wasserstrom 2009). Since 1978, China's open-door policy has reversed this situation: Shanghai's urban identity has once again been promoted as an international city, and the myth of the cosmopolitan and vibrant metropolis of the pre-1949 era has been revived to advertise the city and its future destiny as a global metropolis ( $\mathrm{Lu} 2002$; Wu 2003; Wu
2007; Chen 2009; Greenspan 2014). In the context of the Chinese Communist Party's national economic strategy of attracting capital and talents from abroad, making China a target of inbound migration (Pieke 2012), Shanghai has again become the destination for an increasing flow of incoming foreigners from all over the world. A multinational community currently lives in the metropolis, including corporate business professionals, small-business entrepreneurs, teachers, and students.

Literature on foreign migration to Shanghai has usually focused on the experiences and perceptions of foreign residents, in order to analyse the emergence of a new transnational and cosmopolitan culture and society (Lagerkvist 2013; Stanley 2013; Farrer, Field 2015; Farrer, Greenspan 2015). However, this literature deals primarily with the highly-mobile Western transnational elites of business and academia, which marginalises the experience of other communities living in the metropolis. Despite this limitation, ethnographic research clearly shows how the lives of foreigners in Shanghai can be complicated by contradictory wishes and feelings, oscillating between a desire to maintain distance from the local society, and an aspiration to be integrated through various "strategies of emplace- 
ment"(Farrer 2010). At the same time, the possibility of integration in the local context is somewhat limited by the way multiculturalism is managed by the Chinese government, which is apparently inclined to preserve urban segregation and cultural differentiation between native Chinese and foreigners (Farrer 2014a).

This paper takes a different, but complementary, perspective; it aims at exploring the Chinese discourse on Shanghai's foreign communities to understand how Shanghai's image as a cosmopolitan and multicultural metropolis accommodates the importance of cultural nationalism in contemporary China. Considering Shanghai's central place in the official Chinese historical narratives of anti-imperialist and nationalist struggles during the last century, foreign presence could be a sensitive issue. From a Chinese perspective, paths of symbolic integration of foreigners into Shanghai's social and cultural identity must take into account the need to place Chinese culture at the core of its urban identity. In this sense, the key question is whether Shanghai could be an illustrative case of what Lisa Rofel has called "a domestication of cosmopolitanism by way of nationalist-inspired renegotiation of China's place in the world" (Rofel 2012:448). Investigating the emergence in Shanghai of what I tentatively call an urban "sinicised cosmopolitanism", the meaning of foreign presence in the city will be analysed as it is constructed in local migration policies and in the Chinese media's narratives. Both fields of enquiry can offer some insights on the conceptualisation of the role of foreigners in Shanghai's affirmation as a Chinese city of global relevance.

\section{Foreign presence in contemporary Shanghai: an overview}

In recent years, the issue of inbound migration has increasingly reached the attention of official and academic institutions in China and abroad, becoming a topic of scientific research and public interest (Pieke 2012; Wang et al. 2016).

The Sixth Population Census, held in 2010, was the first Census to register foreigners who had resided in China for more than three months at that time. The Census actually counted residents in China who were "coming from outside the border" (waijing renmin), meaning the people who were subjected to customs duties at the entrance of mainland China (Song 2013). This category includes two groups of foreigners whose relationship to China is fundamentally different (Pieke 2014). The first group includes the residents from Hong Kong, Macao, and Taiwan (Xiang, Ao, Tai jumin), who are not considered real aliens, since they are either Chinese citizens residing in the Special Administrative
Regions, or they are ethnic Chinese living in the island of Taiwan that Beijing still considers a "rebel province". The second group includes the residents from all other countries, who are considered to be true foreigners, since they have a "foreign nationality" (waiji).

According to the 2010 Census, 1,020,145 foreigners were living in China (Xinhua News 2011), including 592,832 foreigners not coming from Hong Kong, Macao, or Taiwan - slightly more than half. This number underestimates the true magnitude of foreign presence, because it does not consider short-term sojourners.

Large cities and the most developed areas - such as Beijing, Guangzhou and the whole Guangdong Province, and Shanghai - are the most attractive places for migrants. Foreigners in Guangdong and Guangzhou mostly come from Hong Kong and Macao. Conversely, Shanghai primarily attracts foreigners coming from other areas.

In 2011, the Shanghai Municipality Statistical Bureau presented its first detailed report about foreign presence in the city, primarily based on data from the Population Census (Shanghai Municipality Statistical Bureau 2011). In 2010, there were 208,300 "persons from outside the border" (waijing renyuan) living in Shanghai. Most of them, $68.7 \%$ of the whole, were foreign nationals (waiji). Nevertheless, in spite of its image as the most Westernised metropolis of the People's Republic, the majority of Shanghai's foreign population is Asian: $20.7 \%$ are Japanese, and $13.8 \%$ are South Korean. Looking at Western migrants, $16.5 \%$ of the total migrant population are from the United States, 5.2\% are French, and $4.8 \%$ are Germans.

The presence of foreigners in the city has been characterised by concentration into certain districts. Data from the 2010 census reveal that Pudong New District, Changning District, and Minhang District account for $59.8 \%$ of the city's foreign residents; and $21.1 \%$ of them live in Hongqiao Town in Minhang District, Huamu Street in Pudong New Area, and Hongqiao Street in Changning District (Shanghai Municipality Statistical Bureau 2011).

This spatial concentration is the outcome of the interplay of political, cultural, and economic factors. Historically, since the early 1950s, housing segregation of foreigners has been a fundamental policy of the Chinese Communist Party, as a consequence of the basic dichotomy between an "inner" (nei) and an "outer" (wai) realm (Brady 2003). In the last thirty years, this attitude continued to influence the housing policy adopted by local governments concerning foreign residents. New neighbourhoods were built in most important Chinese cities, designed to cater to 
the residential needs and tastes of expatriates, which were deemed more sophisticated than those of Chinese citizens. In Shanghai, new residential compounds designed to become "foreign enclaves" have been built since the early 1990s in specific districts opened to foreign investments and activities, reflecting political choices as well as economic interests (Wang, Lau 2008; Chung 2014).

The most well-known example is the Gubei New District in Changning District, close to Hongkou airport. It is a rapidly-growing modern neighbourhood of gated communities, provided with modern commercial facilities, services, and international schools. Currently, besides a huge number of Taiwanese, the district is mostly inhabited by Japanese and South Korean sojourners.

In recent years, the policy aimed at favouring residential concentration of foreigners has become less appropriate in a changing reality (Chung 2014). The current trend regarding foreigners' residence is towards the emergence of mixed neighbourhoods, with local people living alongside foreigners. Though we do not have any systematic data, information from online real estate agencies and from Shanghai expat websites provide some insights. Districts such as Jing'an, Luwan, Huangpu, and Xuhui, for example, are promoted as suitable areas because they are simultaneously rich in comforts and facilities, while also having a strong local historical and cultural flavour (HomeyShanghai 2017). Expat websites have many questions and opinions about the best districts in which to live, and participants usually suggest choosing Jing'an, Xuhui, or Luwan as the best accommodation options offering the right mixture of international housing standards and local flavour, at least in central districts. Nevertheless, the fundamental factors influencing choice of residence in the metropolis are income, job, and family, consequently also affecting the opportunity for contact and interactions with Chinese residents.

The official data about foreigners' places of residence in Shanghai do not necessarily reflect the actual state of things. Similarly, not much information is available about the occupational profile of foreigners in the metropolis, either. According to the statistics of the Shanghai Municipal Security Bureau, in 2010, employees of foreign ventures were actually the most numerous, amounting to about $60 \%$ of the total; overseas students, and foreign experts, were far behind (Shanghai Municipality Statistical Bureau 2011). A recent Chinese report reveals that highly-skilled foreign personnel are mostly concentrated in the high-tech manufacturing industry, the software industry, finance, and healthcare (Ma 2016).
The reality is more complex. Shanghai's foreign community also includes young job-seekers, foreign teachers, and small-business entrepreneurs in the service sector. The job market for foreigners in Shanghai is still a mostly unexplored topic, but some ethnological research has partially investigated foreign workers' perceptions, revealing how different job markets, which require different skills for career success and social recognition, determine foreigners' job experiences in Shanghai (Stanley 2013; Farrer 2014b).

Though not exhaustive, all these data hint at the great complexity of foreign presence in Shanghai. Ethnicity, nationality, social and economic status, professional and cultural backgrounds, gender, and age will all greatly influence foreigners' experiences and their attitude towards Chinese culture and society. This complexity rarely transpires from Chinese official discourse on foreigners in Shanghai, which heavily focuses on the impact of their presence for Shanghai's rise as an international metropolis.

\section{Making Shanghai the home of world talents: Shanghai foreign experts in local immigration policies}

Shanghai's immigration policies basically mirror the principles elaborated by the Chinese authorities at national level, but they are also influenced by local plans for the development path of the metropolis. The legal and administrative framework concerning foreigners in China has changed in recent years, reflecting the government's need to have new instruments both to control and select migrants' flow into the country.

Restrictions on immigration have become increasingly evident. For example, one of the most interesting innovations in the last decade has been the issuing of "green cards", or permanent residence permits - a practice which was only officially made systematic in 2004. Eligibility for these permits has been quite restricted; they can only be given to "high-level foreign personnel who hold posts in businesses which promote China's economic, scientific and technological development or social progress, foreign citizens who make relatively large direct investment in China, foreigners who have made outstanding contributions or are of special importance to China, and foreigners who come to China to be with their families" (Ministry of Public Security, Ministry of Foreign Affairs, 2004). Overall, it remains quite difficult to obtain a permanent residence permit in China. Though there are 600,000 foreigners in China, only an average of 250 such permits have been issued every year from 2004 to 2014 (Boehler 2013).

The same attitude seems implicit in the 2013 Exit and Entry Administration Law, which replaced the pre- 
vious laws promulgated in the 1980s and 1990s (Zhu, Price 2013; Bork-Hüffer, Yuan 2014). The 2013 law is aimed at regulating immigration to China, primarily against the so-called "three illegalities" (sanfei), which are illegal entry, illegal stay, and illegal job. The law originated from the national government's perception that there were several sources of uncontrolled immigration flow and activities of foreigners in China primarily in the south-western border areas, such as Yunnan Province, where there is a high presence of illegal migrants, as well as in some southern cities, especially Guangzhou, where there are numerous communities of African expats (Zhang 2008; Pieke 2012). For example, some foreigners were able to remain in China after the expiration of their visa or sojourn permit. Moreover, the job market was being distorted by the number of foreign students who used to work for foreign enterprises without appropriate visas and work authorisations.

The struggle against illegal immigration is strongly connected to a priority of strengthening the image of a national and local government capable of controlling foreign presence and affirming its sovereignty, a pivotal principle in the Chinese Communist Party's policy towards foreigners (Brady 2003). It is also consistent with the importance of shaping foreign presence in China according to a strategy of upgrading the domestic economic and cultural profile of the nation in global competition, making China an attractive destination for highly-skilled personnel in advanced fields, the so-called "talents" (rencai) (Wang 2012; Yeoh, Huang 2013).

Since the 1990s, the government of the People's Republic of China has elaborated several plans to make the working and living conditions in China more inviting for "foreign experts" - professionals whose expertise and educational credentials are considered important for improving China's global competitiveness. These programmes became more ambitious in the 2000s and have been quite successful in attracting Chinese scholars and scientists, who had previously relocated to foreign nations, to return to China. However, they have been less effective in attracting foreigners of non-Chinese origins (Farrer 2014b).

It should be noted that, in common usage, the term "talent"- the keyword of Chinese migration's policy - is often conflated with "foreign expert" (waiguo zhuanjia), a term long-used to indicate professionals and consultants working in Chinese economic, scientific, and educational institutions. The office in charge of managing the inflow of foreign experts is the State Administration of Foreign Experts Affairs (SAFEA), an agency of the State Council. The concept of "foreign expert" is quite inclusive, also being used to indicate ordinary foreign teachers of English and other foreign languages in schools and universities, which are very popular jobs for foreigners in China. National policies have recently been increasingly restricting the criteria - especially in terms of educational level and expertise - to be defined as a foreign expert, reducing access to Chinese job markets and residences for foreigners perceived as insufficiently qualified. In autumn 2016, the SAFEA issued stricter classification criteria for foreigners asking for a residence permit to work in China, individuating three categories of foreigners: top talents, professional talents, and unskilled or service-sector workers (Zhang 2016). The not-so-secret goal is to facilitate the arrival in China of top talents, while restricting the possibility of residence for unskilled workers. If this policy reflects the priorities of China's economic strategy, its implications also hint at the government's aspiration to internationally project an image of China as a future superpower, attracting the best human and intellectual resources at global level.

In Shanghai, the 2013 law was deemed necessary to control and limit "illegal immigration", which was mainly identified as overstays of expired permits by migrants from south-east Asian countries working in the service sector, and employment of foreign students in Chinese or foreign enterprises. Similarly, as Shanghai aspires to become an innovation hub, its local government and SAFEA's local branch have actively embraced the goal of making the metropolis a comfortable home for global talents of both Chinese and foreign origins. Shanghai Municipality expects that by 2020 , the numbers of foreign experts living in the metropolis will soar to 210,000 , from the current 160,000 (Zhao 2014).

Policies concerning visa and residence permits in Shanghai have been explicitly aimed at facilitating the operations of the multinational corporations, providing their personnel with better treatment concerning longterm residence. The critical point has been set out in the complex procedures and limits of the 2013 law, to which several adjustments have been planned in Shanghai. In 2015, the Shanghai Municipal Government released the Administrative Measures of Shanghai on Residence Permits for Foreign Talents, which should be enforced for five years (China Briefing 2015). According to these measures, a foreign residence permit's period of validity will be extended up to 10 years on a case-bycase basis, depending on the applicant's age, academic qualifications, field of specialisation, work experience, employment contract, and other criteria. This opportunity is also offered to foreign experts or high-level specialists; to specialists from Hong Kong, Macao, and Taiwan; to foreign students who are studying at a local 
Chinese university; and to students or specialists who have a Chinese passport and a permanent residency in a foreign country, but do not have local residence in Shanghai. The inclusion of foreign students in the group deserving an opportunity to stay is connected to the desire to promote the city's academic system as a global point of attraction for talents in the worldwide education market.

It is evident that higher education is considered the main factor in determining the possibility of qualifying for long-term residence, regardless of the geographical and career mobility which usually characterises the global professional elite. The promotion of longterm residence is aided by granting migrants and their family members, access to the social security system and educational preferential policies in Shanghai's local schools.

On the whole, local migration policy suggests that the authorities' idea of Shanghai's identity as an international metropolis is influenced both by ideological and cultural bias. The attraction of the city to foreign migrants is a sign of its increasing connection to the global economy and mobility of skilled people. But the government's attempt to shape migration to Shanghai seems to be predominantly guided by the idea that only the presence of an affluent, transnational, and highly globalised economic and cultural elite - the much-needed talents - could represent a competitive factor in transforming Shanghai into an internationally-leading metropolis. The discourse on the need to select foreign talents worthy of working and living in Shanghai is shaped by the nationalist concern to have a foreign population which fits the image of the city as a rich, innovative, and global metropolis in a powerful China. A newspaper commentator wrote explicitly (Ma 2016):

Although the numbers of overseas visitors and foreigners are far ahead than other places, according to the Report on Talents of the Shanghai Innovation Center, Shanghai is currently facing a shortage of senior talents and high-profile research talents. Only $4.5 \%$ of talents working in Shanghai have a doctorate degree, a percentage lower than the national average of $5.3 \%$. Moreover, the Shanghai local talents' industry experience is lower compared to the standards of foreign cities, we lack skilled personnel, therefore, to attract basic research, industry-experienced senior talents is the first problem in making Shanghai an innovation centre.

The official discourse on foreigners in Shanghai, as it emerges from local immigration policies, emphasises the educational quality of migrants in order to boost the image of the metropolis as a would-be competitive place in technological and scientific fields. Concerns about the impact of foreign migration on Shanghai's cultural identity as a Chinese city are apparently set aside, but this only appears to be the case. Knowledge of Chinese language is not required to receive preferential treatment as a foreign expert, but as previously discussed, foreign nationals of Chinese origin and Chinese citizens permanently-resident abroad have been the main beneficiaries of Shanghai institutions' talent-hunting abroad. This ethnic factor is quite strong; people with Chinese origins are given preferential treatment for migration and long-term stays, since Chinese returnees - especially scholars, scientists, and businessmen who had studied abroad and had taken foreign nationality - and economic and cultural elites of Chinese origin are a key factor in increasing Shanghai's cosmopolitanism without betraying nationalist pride (Pan 2009; Xiang 2011).

Moreover, the discourse regarding foreign talents in Shanghai marginalises a significant part of the foreign population in Shanghai - foreign graduates and young inexperienced professionals who, attracted by the myth of Shanghai as a city of opportunity, have been looking for chances in the metropolis. In practice, the position of these career-seekers is weaker than employees of multinational corporations and consultants to Chinese government institutions. Worse yet, the rising cost of living in the metropolis makes their economic conditions more difficult than they hoped, so their lifestyle is well below the standards of the affluent elite of expatriates working for large multinationals and foreign enterprises. Unsurprisingly, in the last few years, the idea that China - and Shanghai - could be the new career frontier for Western-educated youth has had to come to terms with an increasingly complicated reality (Farrer 2014b).

The possibility that these foreigners could also influence the city's social and cultural development is considered quite marginal in the official discourse implied in Shanghai's migration policies. A recent comment in The Global Times, an English-language Chinese newspaper - while discussing the Magnolia Silver Prize, which has been awarded by the Shanghai Municipality since 1989 to eminent foreigners who have contributed to Shanghai's development but don't necessarily live in the city - suggested that a new prize should be created to recognize foreigners living in Shanghai "who don't wear suits but still contribute to Shanghai society in unseen ways that often go unacknowledged by the government" (Cottrell 2015). 


\section{Laowai and yang jumin: narratives of foreigners in Shanghai's media}

Media discourse is an important source for understanding the significance officially attributed to foreign presence as it concerns Shanghai's urban identity, because the media defines the terms for open and legitimate debate on issues of public interest. In contemporary China, foreign migrants are certainly a topic of interest, as can easily be seen by the space dedicated to this subject in both traditional and online media (Song 2015; Au 2009). Shanghai is no exception, but since a full systematic survey of reports and editorials about foreigners in the metropolis media is beyond the scope of this paper, we will limit our analysis to Chineselanguage press reports available from the website of the Chinese Communist Party's official mouthpiece, Jiefang ribao (Liberation Daily). Since it collects all the most important articles on any topic in the Chineselanguage press, it could be deemed representative of the range of official narratives about alien communities in Shanghai in the last five years.

From a general point of view, articles on this topic in Chinese newspapers focus on two themes. On the one hand, press stories about foreigners clearly emphasise how Shanghai has become a cosmopolitan metropolis whose native inhabitants are ready and even eager to live in an international society. On the other hand, they also tend to stress that the city's internationalisation implies a two-way process: as Shanghai's local institutions and people must adapt to foreign presence, foreigners must also be at least partially "sinicised" (zhongguohua), to be integrated into the social and cultural texture of the metropolis. This suggests an idea of Shanghai as a place where a "sinicised cosmopolitanism" could be built as the result of the cultural accommodation of foreigners to China. This process is described not as spontaneous, but rather guided from above, demonstrating the local authorities' ability to manage Shanghai's internationalisation without weakening its Chinese identity.

In fact, Chinese discourse about foreigners in Shanghai's media is framed by two main concepts. The first is the concept of the foreigner as laowai, a popularly-used colloquial term which emphasises cultural differences. The second concept is the idea of yang jumin (foreign resident), which hints at the fact that foreigners living in the city are a different category of urban citizens, but they are still part of Shanghai's local society. It is also worth noting that both terms, laowai and yang jumin, implicitly refer mainly to white Western people, suggesting that the international identity of Shanghai is primarily connected to the West, despite the fact that, in reality, Asian foreign residents are an important component of the expat community in China.

Making use of both notions of laowai and yang ju$\mathrm{min}$, the media narratives on foreigners in Shanghai tends to impart the idea that they constitute a world apart from the local society. Differences between foreigners and Chinese citizens can engender cultural conflicts, but they also enrich the profile of Shanghai as an international metropolis. At the same time, the possibility of alien residents' integration into the city's society and cultural life is envisaged as a consequence of both the increasing internationalisation of the city and the foreigners' attraction to Chinese culture.

Issues of urban space and lifestyle occupy a dominant position in all the narratives about foreigners in Shanghai. Their most evident feature is that foreigners, as laowai, live in distinctive districts and maintain most of their own customs and habits (see Wang et al. 2015). Their presence is seen as a sign of an increasing internationalisation developing under the aegis of national and local authorities, which consequently does not imply any kind of cultural weakening of China. An article on foreigners' presence in Shanghai offers a telling example on this point (Mei 2012):

According to data of five years ago, about 160,000 foreigners (laowai) from more than 160 countries worldwide live in Shanghai. Today, foreigners are Shanghai urban brand. Walking in the streets of Shanghai, passing from time to time there will be a foreigner that tells you politely "sorry"; some districts where there is a international atmosphere give people the wrong impression of being abroad: new Shanghai landmarks as Xintiandi and Tianzifang, are gradually "occupied" by foreigners, if you find yourself in the middle of a group of blond haired foreigners, you can have a subtle feeling of being out of place. Walking through the places that foreigners love the best, you can observe foreigners living as they like to live. Maybe have they occupied Shanghai? But what is inadvertently revealed to us still reminds us that here foreigners are still guests.

This alien presence gives Shanghai the international flavour and pluralistic identity it aspires to have as a modern metropolis. Since local society is able to host and welcome differences, foreigners can preserve their "otherness". They embody a peculiar lifestyle - characterised by intense sociality, bar culture, and attendance of recreational events late into the night - which is different from Chinese customs (Yang 2014). Shanghai's most important feature is 
to permit foreigners to be free from any necessity to adapt their habits to local context (Qian et al. 2015): Shanghai is a perfect place for foreigners, since, as Chinese interviewee said: "Shanghai's laowai can preserve more their lifestyle. Shanghai is more internationalized, there are more foreigners, more choices of jobs for foreigners, whole life support for eat, drink and fun, if you go out, you can find a Western restaurant, so which is the necessity to go to a Chinese one? If you can find a bar at every corner, why you can't simply spend your free time according to your habits?... the greatest advantage of living in Shanghai for a laowai is that he/she does not have to deliberately be "down to Earth" [that is, adapt to local common people's lifestyle Author's note]

The existence of districts which guarantee a high visibility of foreign presence in contemporary Shanghai has a touristic value for the city's image. One example is Laowaijie, the Pedestrian Street of Foreigners, which is full of foreign bars and restaurants, and is publicised as the ideal place to enjoy the international flavour of the metropolis. As James Farrer has argued (2014a), this place reveals that multiculturalism in Shanghai is essentially built on an idea of spatial segregation and preservation of cultural differentiation. On the whole, media discourse tends to stress that international districts in the city are a sign of the modernity, progress, and cosmopolitanism (Wu 2016):

"Elegance and leisure" are Changning

District's characteristics, and nowadays more and more foreign residents come to live here, adding another feature, that is "pluralism". Shanghai 28 consular offices, more than 120 diplomatic officials, nearly 3,000 foreign-funded enterprises, offices from 150 countries and regions, about 69,000 foreigners. Multiculturalism has become a "neighbor", residents of different language, nationality, different skin colour make Changning a "little United Nations". As one of the most cosmopolitan urban districts in Shanghai, Changning is moving towards the path of becoming an international model district of innovation, fashionable vitality, green residences and sustainability, constantly improving international education, health, business services, in order to make foreign national residents do not feel "uprooted" and helpless, but develop a kind of attachment as "the other's home is also my hometown" (taxiang ji guxiang).
Since laowai live differently from the Chinese, at any rate, it is not always easy to accommodate this alien presence. Management of urban space can become a controversial issue. A well-known example is the controversy between local residents and foreign customers on Yongkang Road, in the French Concession - another street where there used to be a high concentration of foreign-style bars and nightclubs. The noise and confusion produced by foreigners drinking, chatting, and having fun late into the night caused protests from the local residents, who were adamant in saying that the street had become "a heaven for foreigners and a hell for locals"(Zhou 2013). The controversy lasted until summer 2016, when the district government ordered most of the bars on the street to be deemed illegal and shut down.

The media's emphasis on cultural diversity as the brand of Shanghai should not obscure how the accommodation of foreign presence in urban social and cultural life is presented as a way to affirm the importance of Chinese culture for the identity of the metropolis. Rather, knowledge of - or better, attraction to - Chinese tradition and culture is suggested as a fundamental premise for foreigners' emplacement in the city as residents.

The promotion of Chinese culture among foreigners is part of a more complex process of governing alien nationals' communities. As foreigners become a structural component of urban life, their presence requires new instruments of administration, which can help solve the problems that originate from linguistic and cultural diversity. This goal could be reached with the help of so-called "foreign neighbourhood committees" (shewai juweiyuan), whose function is to support the Chinese Communist Party's traditional urban committees for the concerns of managing foreign residents (Lin 2008; Lu et al. 2009; Chen 2012). As an interviewed foreigner said: "the concept of neighbourhood committee used to be unknown to foreigners, if the there is a problem in the house, we look for the property manager; in case of neighbourhood disputes, we call the police. Nobody would go to the neighbourhood committee" (Lin 2008). But by extending Chinese governance methods to foreign communities, Chinese local authorities see the development of these institutions as the most important tool they have for managing an international society. These committees are called to work on several duties, from administrative issues to the organisation of services for foreign residents (Chen 2012).

Media narratives about these committees emphasise the relevance of Chinese culture, in order to create "harmonious" communities and help foreigners feel 
at home. One example is the coverage of the earliest committee of this kind, now considered a model - the Ronghua Community in the Gubei district (Wei 2012; Zhou 2012). In this community, some foreign residents formally became counsellors on the district committee, under the guidance of local Chinese Communist Party cadres. These counsellors are required to act as cultural brokers between the two communities, due to their competency in Chinese language and culture (Yan 2015), matching Chinese professionals in cultural mediation.

The role of foreign neighbourhood committees is specifically publicised as facilitating "friendship" and increasing foreign residents' knowledge of Chinese culture. The promotion of initiatives such as classes on Chinese language, music, painting, and even opera, is presented as the fundamental path to create cultural cohesion among foreign residents. For example, according to a newspaper report, the community in Changning District has organised courses on the Shanghai dialect, tea rituals, and Chinese-language puppet theatre, dance, and songs, all greatly appreciated by foreigners of different nationalities living there (Wu 2016; Xu 2016). It is worth noting that the notion of Chinese traditional culture supported by these kinds of activities is quite naive, focused on Chinese folk customs, such as cuisine, music, traditional festivals, and popular art. But what counts, according to the media, is that Shanghai foreigners must be given the possibility to discover and appreciate the richness of Chinese tradition (Mao 2016):

On February 21, the Australian Mark made a special trip to fly back to Shanghai in the evening, in order to be able to go to old town Fengiing to experience the traditional Chinese Lantern Festival. Mark was not the only one to attend the Lantern Festival in Fengjing, among those who participated, there were several "foreign residents" living in the Chengjiaqiao invited by the Changning District Chengjiaqiao urban community, they included people from more than ten countries, as the United States, France, Britain, Australia. Almost 50 foreign friends came to the town of Fengjing for the Lantern Festival, painting traditional farmers' paintings and feeling the charm of traditional Chinese folk culture. [...]"As soon as I got off the car, the beauty of Fengjing town has enchanted me, this place is so different from the Shanghai area and from my hometown. The landscape, culture, folk customs... all is wonderful and has the flavour of an- tiquity. It has been really a great fortune that our Changning community and Fengjing town have arranged this activity for the Lantern Festival, permitting to us foreigners to see so special Chinese traditional folk customs and eat delicious sweet dumplings", the words of Nicholas are full of excitement.

This kind of discourse is obviously conflated with official propaganda, but it actually mirrors an evident nationalist anxiety. The presence of foreign-lifestyle places and customs in the city is increasingly presented by the media as a facet of its modern international face. But the same narratives also construct the public perception that foreigners become part of Shanghai as they are ready to recognise and admire its "Chinese" identity. The emphasis on foreign appreciation for Chinese culture gives the reader the idea of a "sinicised cosmopolitanism" as Shanghai society's openness to the world is called upon to reshape, but not to marginalise, the notion of the centrality of Chinese national culture for its urban identity on the global stage.

\section{Conclusions}

Though foreign presence in the city is considered fundamental for Shanghai's branding as an international metropolis, the discourse produced by local authorities and media about the alien migrants in the city reveals several points of ambivalence about this process and its impact on the city's cultural identity.

An analysis of migration policies suggests that Shanghai's local authorities aspire to shape migration towards the metropolis to enhance its identity as a global capital city in business, culture, and science, and as a pole of attraction for affluent cosmopolitan elites. In this way, migration policies tend to weaken the representation of Shanghai as a city of opportunities excluding foreigners who do not belong to the global elite of managers, CEOs, and highly-skilled experts, but could be equally important in supporting its international image. From this perspective, Shanghai's discourse on cultural internationalisation is subordinated to China's aspiration to affirm itself as a world economic and cultural power.

Similarly, multiculturalism as a sign of Shanghai's contemporary development is clearly articulated in media coverage about laowai. But at the same time, alien residents' symbolic legitimisation as members of the city's community is explicitly connected to their positive attitude and appreciation of Chinese traditional culture. Shanghai is portrayed as a place where foreigners can preserve their lifestyle and differences, without marginalising or rejecting Chinese customs and values. This approach to multiculturalism implies the global 
acknowledgement of Chinese culture as a fundamental component of a cosmopolitan urban society.

This official discourse on foreign communities in Shanghai serves to affirm Shanghai's internationalisation without jeopardizing its Chinese identity. The preservation of this identity is fundamental for the national government to make the metropolis the nucleus and the symbol of China's rise as a global power. Recalling the past, the international face of Shanghai is once again a screen onto which the Chinese nation's hopes and fears are projected.

\section{References}

$\mathrm{Au}, \mathrm{A} .2009$. Laowai of all kinds permeate Shanghai TV [online], [cited 8 September,2016], Global Times. 16 June, 2009. Available from Internet: http://www.globaltimes.cn/content/437437.shtml

Bérgère, M. C. 2009. Shanghai. China's gateway to modernity. Stanford California: Stanford University Press.

Boehler, P. 2013.Under China's new immigration law, harsher fines for illegal foreigners, South China Morning Post. 1 July, 2013.

Bork-Hüffer, T.; Yuan, Y.-I. 2014. The management of foreigners in China: changes to the migration law and regulations during the late $\mathrm{Hu}$ Wen and early $\mathrm{Xi} \mathrm{Li}$ eras and their potential effects, International Journal of China Studies 5(3): 571-597.

Brady, A. M. 2003. Making the foreign serve China: managing foreigners in the People's Republic. Lanham: Rowman \& Littlefield.

Chen, X. 2012. Nianhao shewai shehui guanli zhe benjing [The social management of foreign residents community], Shanghai daren yuekan 2012(9):19-20. (in Chinese)

Chen, X. (Ed.). 2009. Shanghai rising. State power and local transformation in a global megacity. Minneapolis: University of Minnesota Press.

China Briefing 2015. Administrative measures of Shanghai on residence permits for foreign talents [online], [cited 5 September 2016], China Briefing. 12 August, 2015. Available from Internet: http://www.china-briefing.com/news/2015/08/12/ retaining-foreign-talents-in-china-shanghai-and-beijingimprove-foreign-residence-permit-rules.html

Chung, P. 2014. Living globally: exploring the need for foreign enclaves in contemporary Shanghai: MA Thesis. Faculty of Architecture and Planning, Columbia University.

Cottrell, C. 2015. Shanghai Magnolia Awards should recognize all expats [online], [cited 5 September 2016], The Global Times. 18 October, 2015. Available from Internet: http://www.globaltimes.cn/content/947716.shtml

Farrer, J. 2010. "New Shanghailanders" or "New Shanghaiese": Western expatriates' narratives of emplacement in Shanghai, Journal of Ethnic and Migration Studies 36(8): 1211-1228. https://doi.org/10.1080/13691831003687675

Farrer, J. 2014a. Foreigner street: urban citizenship in multicultural Shanghai, in N.-K. Kim (Ed.). Multicultural challenges and redefining identity in East Asia. New York: Routledge,17-43.

Farrer J. 2014b. China wants you. The social construction of skilled labor in three employment sector, Asian and Pacific Migration Journal 23(4): 397-420.

https://doi.org/10.1177/011719681402300405
Farrer, J.; Field, A. 2015. Shanghai nightscapes. A nocturnal biography of a global city. Chicago: Chicago University Press. https://doi.org/10.7208/chicago/9780226262918.001.0001

Farrer, J.; Greenspan A. 2015. Raising cosmopolitans. Localized educational strategies for international families in Shanghai, Global Networks 15(2): 141-160. https://doi.org/10.1111/glob.12068

Greenspan, A.2014. Shanghai future. Modernity remade. London: Hurst and Company. https://doi.org/10.1093/acprof:oso/9780190206697.001.0001

Homey Shanghai. 2017. Shanghai neighbourhoods [online], [cited 30 January 2017]. Available from Internet: http:// www.homeyshanghai.com/shanghai-apartments-rental/ neighborhoods-introduction/

Lagerkvist, A. 2013. Media and memory in New Shanghai. Western performances of futures past. New York: Palgrave McMillan. https://doi.org/10.1057/9781137014658

Lin, L. 2008. Yang jumin you shi ye zhao juminhui [When foreign residents have problems look for the residents committee], [online], [cited 20 August 2016], Huanqiu shibao. 18 July, 2008. Available from Internet: http://www.jobsitechina.com/news/news-nr2087.html (in Chinese)

Lu, H.2002. Nostalgia for the future: the resurgence of an alienated culture in China, Pacific Affairs 75(2):169-186. https://doi.org/10.2307/4127181

Lu, H.; Ren, Y.; Chen, X. 2009. Downward pressure and upward bubbling. Global influence and community (re)building in Shanghai, in X. Chen (Ed.). Shanghai rising. State power and local transformation in a global megacity. Minneapolis: University of Minnesota Press, 191-214.

Ma, D. 2016. Zai Hu gongzuode waiguoren sicheng bian'ai xianjin zhizaoye [Foreigners working in Shanghai all prefer the advance manufacture industry], [online], [cited 2 February 2017], Xinmin wanbao. 12 August, 2016. Available from Internet: http://www.cet.com.cn/cjpd/jy/1803443.shtml?from $=$ timeline\&isappinstalled $=0$ (in Chinese)

Mao G. J. 2016. Yang jumin laidao qiannian guzhen Fengjing nao Yuanxiao [Foreign residents came to the antique city of Fengjing for the Lantern Festival], [online], [cited 15 January 2017], Jiefang wang. 22 February, 2016. Available from Internet: www.jfdaily.com/shehui/bwyc/.../ t20160222_2135842.html (in Chinese)

Mei, A. 2012. Laowai zai Shanghai huode ziyi [In Shanghai foreigners lived quite wantonly], [online] [cited 8 August 2016], Jiefang Ribao. 13 June, 2012. Available from Internet: http://newspaper.jfdaily.com/sjfwdb/html/2012-06/13/content_822357.htm (in Chinese)

Ministry of Public Security; Ministry of Foreign Affairs. 2004. Regulations on examination and approval of permanent residence of aliens. Decree n.74, August 2004.

Pan, L. 2009. Of Shanghai and Chinese cosmopolitanism, Asian Ethnicity 10(3): 217-224. https://doi.org/10.1080/14631360903189542

Pieke, F. N. 2012. Immigrant China, Modern China 38(1): 40-77. https://doi.org/10.1177/0097700411424564

Pieke, F. N. 2014. Emerging markets and migration policy: China [online], [cited 20 September 2016] Istitut Français de Relations Internationals. Available from Internet: https:// www.ifri.org/en/publications-cerfa-ifri/emerging-markets-and-migration-policy-china-1

Qian B.; Luo Z.; Wei H. 2015. Laowai zai Shanghai: qipo zixingche, jin nongdang lifa [Foreigners in Shanghai: rid- 
ing bike, having an haircut in the lilong], [online], [cited 2 February 2017], Wenhuibao. 11 July 2015. Available from Internet: http://sh.eastday.com/m/20150711/ulai8789965. $\mathrm{html}$ (in Chinese)

Rofel, L. 2012. Between tianxia and post-socialism: contemporary Chinese cosmopolitanism, in G. Delanty (Ed.). The Routledge handbook of cosmopolitan studies. New York London: Routledge, 443-451.

Shanghai Municipality Statistical Bureau.2011. 2010nian Shanghai jingwai renyuan xianzhuang yu tezheng [Foreign population in Shanghai in 2010], [online], [ cited 20 September 2016]. Available from Internet: http://www.statssh.gov.cn/fxbg/201112/237137.html (in Chinese)

Song, G. 2015. Imagining the others. Foreigners on Chinese TV screen, in R. Bai, G. Song (Eds.). Chinese television in the twenty-first century. New York: Routledge, 107-119.

Song, Q. 2013. Waiguoren yu Xiang Ao Tai jumin zai Zhongguo dalu de renkou shehuixue fenxi [A socio-demographic study of foreigners and residents from Hong Kong, Macao and Taiwan in mainland China], Shandong daxue xuebao 2013(2): 89-99. (in Chinese)

Stanley, F. 2013. A critical ethnography of "Westerners" teaching English in China. Shanghaied in Shanghai. London and New York: Routledge.

Wang H. Y.; Chen Y. J.; Luan Y. Z. 2015. Shencheng "Yang jumin" ai zhadui nali [Where Shanghai foreign residents like to go], [online], [cited 15, September 2016], Jiefang ribao. 26 December, 2015. Available from Internet http://newspaper. jfdaily.com/jfrb/html/2015-12/26/content_161147.htm (in Chinese)

Wang, J.; Lau, S. 2008. Forming foreign enclaves in Shanghai: state action in globalization, Journal of Housing and the Built Environment 23(2): 103-118. https://doi.org/10.1007/s10901-008-9103-3

Wang, H. 2012. China's competition for global Talents: Strategy, Policy and Recommendations. Asia Pacific Foundation of Canada Research Report, May 2012. https://doi.org/10.2139/ssrn.2263701

Wang, H. Y.; Zheng J. L.; Miao L. 2016. Zhongguo guoji yimin baogao 2015 [A Report of International Migrants in China]. Beijing: China and Globalization Center, Chinese Academy of Social Science. (in Chinese)

Wasserstrom, J. N. 2009. Global Shanghai 1850-2010. A history in fragments. New York London: Routledge.

Wei, B.F. (Ed.). 2012. Shanghai Gubei: ruhe chuangxing "yang jumin" shequ de shehui guanli [Gubei in Shanghai: how to renovate the social management of foreign residents community], [online], [cited 20 September 2016], Renmin wang. 30 January, 2012. Available from Internet: http:// expo.people.com.cn/GB/57923/228800/231774/16969197. $\mathrm{html}$ (in Chinese)

Wu, C.W. 2016. Changning qunzhong ganshou xilie diaocha: Waiji jumin shuo[Surveys on mass perception in Changning: Foreign nationality residents speak out], [online], [cited 20 September 2016], Wenhui bao. 18 January, 2016. Available from Internet: http://sh.eastday.com/m/20160118/ ulai9183523.html (in Chinese)

$\mathrm{Wu}, \mathrm{F} .2003$. The (post-) socialist entrepreneurial city as a state project: Shanghai's re-globalisation in question, Urban Studies 40: 1673-1698. https://doi.org/10.1080/0042098032000106555

Wu, W. 2007. Shanghai: The evolution of China's future global city, in K. Segbers (Ed.). The making of global city regions:
Johannesburg, Mumbai/Bombay, São Paulo, and Shanghai. Baltimore: Johns Hopkins Univ. Press,113-134.

Xiang, B. 2011. A ritual economy of talents. China and overseas Chinese professionals, Journal of Ethnic and Migration Studies 37(5): 821-838. https://doi.org/10.1080/1369183X.2011.559721

Xinhua News 2011. 593,832 foreigners live on Chinese mainland: census data [online], [cited 10 August 2016], English.news. cn. 29 April, 2011. Available from Internet: http://news.xinhuanet.com/english2010/china/2011-04/29/c_13851456.htm

Xu, Y. F. 2016. Shanghai kaifangshi xiaoqu Gubei: shenghuo hen bianli. Chule wairen lai liu gou, mei juede gu bei sha bu hao [The small open community of Gubei in Shanghai: life is very convenient. Except from outsiders with the dogs, nobody thinks the Gubei is not good], [online] [cited 2 February 2017], Xinwen chenbao. 2 February, 2016. Available from Internet: http://newspaper.jfdaily.com/ xwcb/html/2016-02/25/content_175909.htm (in Chinese)

Yan, J. 2015. Foreigners play role in community relations [online], [cited 10 August 2016], Shanghai Daily. 14 January, 2015. Available from Internet: http://www.shanghaidaily. $\mathrm{com} / \mathrm{metro} /$ expat-community/Foreigners-play-role-incommunity-relations/shdaily.shtml

Yang, S. 2014. Laowai kan Shanghai: Yanshi de ditie [Foreigners look at Shanghai: the time extension of the subway service], [online] [cited 20 September 2016], Shanghai guancha. 30 September, 2014. Available from Internet: http://www.jfdaily.com/news/detail?id=1847 (in Chinese)

Yeoh, B.; Huang, S. (Eds.). 2013. The cultural politics of talent migration in East Asia. New York: Routledge.

Zhang, L. 2008. Ethnic congregations in a globalizing city: the case of Guangzhou, China, Cities 25(6): 383-395. https://doi.org/10.1016/j.cities.2008.09.004

Zhang, X. 2016. China improves work permits, [online] [cited 20 September 2016], Global Times. 9 September, 2016. Available from Internet: http://www.globaltimes.cn/content/1005680. shtml

Zhao, W. 2014. City's foreign experts soar past 2015 target, [online] [cited 10 August 2016] Shanghai Daily. 18 July, 2014. Available from Internet: http://www.shanghaidaily.com/ feature/news-feature/Citys-foreign-experts-soar-past-2015target/shdaily.shtml

Zhou, W. 2012. Gubei community center for cross-cultural links, [online] [cited 10 August 2016] China Daily. 21 July, 2012. Available from Internet: http://www.chinadaily.com. cn/cndy/2012-06/21/content_15515958.htm

Zhou, W. 2013. Bar street heaven for expat, hell for resident, [online] [cited 10 August 2016] China Daily. 17 July, 2013. Available from Internet: http://usa.chinadaily.com.cn/ china/2013-07/17/content_16787264.htm

Zhu, G.; Price, R. 2013. Chinese immigration law and policy: a case of "change your direction or end up where you are heading"?, Columbia Journal of Asian Law 26(1):1-28.

\section{LAURA DE GIORGI}

is Associate Professor of Chinese History at Ca' Foscari University of Venice. Her researches have focussed on the history of media and propaganda in modern and contemporary China, and on the history of the relations between China and Italy in the Twentieth Century. 